\title{
Paul Ricoeur's The Course of Recognition: His Last Work and His Last Days
}

\section{Charles Reagan}

This book was Paul Ricoeur's last book, written when he was suffering from a series of old-age related illnesses.In spite of this, he kept to his daily schedule, spending the mornings in his study and the late afternoons receiving colleagues and visitors. The book was published in French less than one year before be died. Since this was the last of his philosophical works, I want to begin and end this paper with some personal notes. I put these notes in italics so that a reader who wants only the philosophical discussion can go directly to that text.

It may seem strange that Ricoeur would begin a book by a catalogue of dictionary meanings and the different order in which two different dictionaries put these meanings. There are two reasons for this: in the Ricoeur home, a dictionary sat on the dining table and was referred to frequently to make a point, to answer a question, to start a philosophical argument, or even end one. Second, Ricoeur took seriously the idea that philosophical issues lie in everyday language and that our language is notpurely neutral, but represents the sedimentation of once-living metaphors and ways of thinking.

With respect to the word "recognition," I recall discussing its meanings with him as early as 1992. At this point, he was fascinated with the word and all of its meanings, but he did not think that there was a coherent philosophical theory of "recognition" that could put into a rational semantic order the various meanings. We talked about the different meanings as if they were completely different words. At one time, we would talk about recognizing an object or a person, other times about the desire to be recognized. In one conversation then, and another conversation a decade later, we spent time thinking and discussing "recognition" in the sense of recognizing the authority of a state or government. Interestingly, this meaning is 


\section{CHARLES REAGAN}

absent from his analysis and I will make this point in my critique. Thus, I was not surprised that he would write a book about "recognition," but amazed that he was capable of doing so in his last days.

In June of 2004, I went to Paris to visit Paul only to find that he was just out of the hospital where he had spent several weeks with heartproblems complicated by an infection. I thought it was the last time I would see him alive. He was very weak and his voice so soft I could barely hear him. In retrospect, I believe that finishing this book left him in a weak state. The difference was that, at the end of bis previous books, he announced the unfinished business and the outlines of his next projects. He was always left with unanswered questions and new issues to explore in his next book. This book ends without any such announcement of a new project. But, this book also showed one of his most admirable traits: he mustered the strength and the courage to tackle one last philosophical problem that had been on his mind for many years.

Ricoeur begins his search for the meanings of "recognition" by consulting the dictionary. He is struck by the progression of meanings and gaps such that "...the definitions run together in such a workable way that the derivation seems to flow like a continuous stream of meanings." For his lexicographical study, Ricoeur chooses the two great dictionaries of the French language, the Dictionaire de la langue française, published by Emile Littré between 1859 and 1872 and usually called just the "Littré." The second dictionary he consulted was the Grand Robert de la langue française, second edition, published in 1985. It is called the "Robert" and the abridged version used commonly is called the "Petit Robert."

In his Preface, and even more clearly in an article of March 1, 1880 ("How I made my dictionary of the French language") Littré says, "I claim nothing less than to give a monograph for each word, that is, an article where everything that we know about each word as regards its origin, its form, its meaning, and its use should be presented to readers. This has never been done before."2 What Ricoeur is searching for is the rule-governed polysemy which links, in a rational progression, the twenty-three meanings of the word "recognition" in the Littré. I cannot, of course, go through all of the meanings in this paper, but I have chosen several which will have philosophical importance as Ricoeur lays out the multiple roles the word has in different, but related, contexts.

"1. To bring again to mind the idea of someone or something one knows [connait]. I recognize the style. To recognize people by their voice, their bearing." 3 This is the first of the meanings that we can call, "epistemic" 
since they have to do with knowing or discovering. "2. To know by some sign, some mark, some indication, a person or a thing one has never seen before. By her bearing, one recognizes a goddess. To recognize a plant on the basis of the description given in a book." What is important here is the sign, mark, indication, characteristic, which makes identification or recognition possible. "3. To arrive at, to catch sight of, to discover the truth of something. People recognized his innocence. One recognizes healthy water by these signs. One recognizes their bad faith." This meaning brings in the idea of a truth claim and so is still in the group of meanings we can call "epistemic" in that they have to do with knowledge.

By the time we get to meaning twelve listed in Littré, "to recognize" in the order of filiation, such as in recognizing a child as one's own is not just identification, but also the conferring of a right. This meaning is in the area we can call the "moral." Meaning fifteen is to avow or to confess, "perhaps a mistake, a debt, an error"(8). Meaning sixteen, to have appreciation or gratitude (as when one might say in French, "Je suis très reconnaissant"), does not exist in many other languages, although in English it is used, for example, in recognizing someone for their gift. ("We would like to recognize Mr. and Mrs. Smith for their gift to the children's fund.”)

In the course of this summary of meanings of the word "recognize," Ricoeur marks an important distinction which will be present throughout his analyses: “...my working hypothesis concerning a possible derivation of meaning on the conceptual plane finds some more encouragement and support in one significant aspect of the enunciation of the verb as verb-that is, its use in the active voice: to recognize something, objects, persons, oneself, one another-or in the passive voice: to be recognized, to ask to be recognized." 4 This is the dividing line between meanings which can be called "epistemic" and ones which are "moral."

The Robert says, "To grasp (an object) with the mind, through thought, in joining together images, perceptions having to do with it; to distinguish or identify the judgment or action, know it by memory." 5 Ricoeur calls this use "identify/distinguish." The first of his three essays on recognition is devoted to recognition as identification. Ricoeur then takes us on one of his typical itineraries through the history of philosophy on this topic, from Plato to Descartes and then to a very long and detailed account of Kant and his introduction of the condition of time to the understanding of the mental act of recognizing. He then changes his approach in an interesting way, asking: what can mis- 
recognition teach us about recognition? He refers to Proust's Time Regained and the episode of the Prince de Guermantes' dinner where all of the guests are his old acquaintances and friends, but are devastated by old age and appear to be wearing disguises. Ricoeur says, "The work of recognition must struggle with the threat of the unrecognizable." ${ }^{6}$

The second of the three essays which make up this book is devoted to "recognizing oneself." He begins with an account of the household recognizing Oedipus, little by little after his return, first by the dog which recognized his master right off. He moves through Aristotle and the recognition of responsibility and then centers his discussion on the "reflexive consciousness of oneself." Here he returns to a distinction he makes in his book, Oneself as Another between the self as idem and self as ipse. ${ }^{7}$ The former is identity through time by a sameness of appearance, characteristics, or style through which we recognize someone as the same person on different occasions, even though time has changed some of those features. The latter is a constancy of character through time, in spite of all of the changes of appearances. Ricoeur says that the promise is the most sure sign of this kind of sameness. I am committed to keeping my promise, even though the circumstances have changed, even though you and I have changed, even though our wants, needs, and desires have changed. The marriage vow is the ultimate form of this kind of self-identity. He refers back to the Robert. "to avow, confess, approve." This is the "transition in meaning from recognition-identification to recognition-avowal." At the heart of self-recognition is the understanding of the capacities to say and to do which constitute the "capable human being recognizing himself in his capacities."'9

Ricoeur's analysis of self-recognition is advanced by the role of memory and promises: "In memory and promises, the problematic of self-recognition reaches two high points simultaneously. The one is turned toward the past, the other toward the future. But they need to be considered together within the living present of self-recognition, thanks to several features they have in common." ${ }^{10}$ Memory is linked to the notion of sameness, idem, while promising is the paradigmatic case of ipséité. "Finally, and this is not the least of their features, both are affected by the threat of something negative that is constitutive of their meaningfulness: forgetting for memory, betrayal for promises." 11

In the third essay, Ricoeur moves from self-recognition to mutual recognition of the other. In Husserlian phenomenology, mutual recognition begins with the self and is extended to the other. For 


\section{RICOEUR'S LAST WORK AND DAYS}

Levinas, it is the other way around. I come to self-recognition through the recognition of the other. I am going to pass over a very interesting account of Hobbes and a very tedious account of Hegel on mutual recognition. But, I do want to turn my attention to an interesting passage about naming as a form of recognition: "In one sense, every birth welcomed is an adoption, not only by the father, but also by the mother, as soon as she has accepted or chosen to 'keep' this fetus becomes 'her' baby and to give birth to it. Both these adoptions were authorized by the system transmitting a family name and choosing a given name for me."12 Recognition by others continues through the birth certificate, baptismal certificate, and passport.

The analysis moves from recognition by the other on the personal level to the recognition of the other on the social level, and then on the juridical level. Here, the other is seen as having rights, protections of self and property, and the status to share equitably in the goods and burdens of citizenship. From the juridical level of recognition, Ricoeur passes to the level of social esteem, to be valued by others. "The most complete model of a recognition of superiority has to be sought in the relationship between a teacher and a disciple." ${ }^{13}$ Here, the words of the teacher have authority; the teacher is recognized as an authority.

Another social form of recognition is that of identity-politics, the recognition of others as groups, such as minorities, the marginal, the different, or the strangers. The rise of multiculturalism in the United States stems from the demand by groups to be recognized as equals and therefore as deserving of equal rights and respect. Many times, the refusal of recognition by others is internalized by members of these groups as self-depreciation, the opposite of self-esteem. The perpetual question is when does a person think and feel that he or she is truly recognized and esteemed? "Does not the claim for affective, juridical, and social recognition, through its militant, conflictual style, end up as an indefinite demand, a kind of 'bad infinity?" ${ }^{\prime 4}$ Ricoeur says that the temptation is a form of the "unhappy consciousness" resulting from a perpetual sense of victimization or persistent pursuit of some unattainable ideal.

Ricoeur illuminates the paradoxes and difficulties of mutual social recognition by reference to the writings of anthropologists on the practice of mutual gift giving among some peoples such as the Maori of New Zealand. I am not going to go into this analysis because I do not see that it illuminates the question of mutual recognition as 
much as Ricoeur does. It is also a place in the book where Ricoeur's writing is dense, even obscure, and somewhat tortured. His usual clarity and eloquence is missing. He concludes this section by saying, "The struggle for recognition perhaps remains endless." ${ }^{\text {15 }}$

Here, I would like to bring to the discussion a very insightful section in Ricoeur's book, Fallible Man where he speaks of the "restless heart," always trapped between its enormous possibilities and its limited actuality. ${ }^{16}$ He refers to the heart which was for the Greeks the seat of the emotions or feelings. He speaks of avoir, pouvoir, valoir, to have or possess, power or capability, and esteem. His question is when will I have enough and when will my possessions be secure? When will my power and my position be secure? And, when will others esteem me and appreciate me for what I am? Ricoeur's answer is that we will never have enough and it is always liable to theft or loss; even the most powerful fall from grace or are removed from power; and, we will never receive the appreciation we believe that we are due from others. This analysis takes us full circle back to the question of social recognition and mutual recognition and the extent to which our self-recognition depends on recognition by others.

What Ricoeur has not addressed is, in my mind, one of the most important meanings of recognition, namely, to recognize a political authority. He did touch on the recognition of authority in the sense of the teacher or expert whose authority is based solely on his/her knowledge, technical expertise, experience, training, etc. But, this type of authority is not the same as political authority. We speak, for example, of recognizing a new state or a new government (Bosnia-Herzegovina or the government of Afghanistan). What is at issue is recognizing a political authority as legitimate. This form of recognition engenders its own paradox: Do we recognize a political authority (President, Dictator, Prime Minister, or King) because he or she is legitimate, or does the recognition by others create the legitimacy? Diplomats and political scientists have invented the distinction of government de facto and government de jure. The first is the government which is in fact in power, whether by a coup or an election. The second refers to a government which is legitimate, even though it may not actually be in power, say a government in exile. An example of this distinction would be the Vichy government of Maréchal Pétain, installed by the Germans in World War II, and the Free French government in exile led by General Charles De Gaulle. Political recognition and the question of sovereignty is a central issue in the discussion of "recognition," so it is odd that it 


\section{RICOEUR'S LAST WORK AND DAYS}

does not attract much of Ricoeur's attention in this book.

Here it may be instructive to turn to an English language dictionary to see the entry on "recognition." I begin by referring to Webster's Universal Dictionary of the English Language (1937):

Recognition. 1. Acknowledgment; formal avowal; as, the recognition of a final concord on a writ of covenant.

2. Acknowledgment; solemn avowal by which a thing is owned or declared to belong to, or by which the remembrance of it is revived.

3. Knowledge confessed or avowed; as, the recognition of a thing present; also memory of it as passed.

4. The act of recognizing; a knowing again.

This series of definitions begins with a legal sense of recognition and then to the avowal sense, for example, to recognize a child as one's own. Only when we get to the last two meanings do we see the epistemological sense arise. Interestingly, in the same dictionary, the word, "recognize" begins with the epistemological meaning, goes to the avowal meaning, and includes the sense of appreciation or gratitude missing from the definition of "recognition." It will be instructive to quote this entry in its entirety:

Recognize. 1. To recall or recover the knowledge of; to perceive the identity of, with a person or thing formerly known; to know again.

Then first he recognized the ethereal guest. -Pope

2. To avow or admit a knowledge of; to acknowledge formally; as, he would not recognize he as an ambassador.

3. To indicate one's acquaintance with (a person), by a bow, a nod, lifting the hat, and the like; as, he passed me without recognizing me.

4. To indicate appreciation of; as, his townsmen recognized his merit by electing him mayor.

5. To review; to reexamine; to take cognizance of anew.

So, one may ask, where is the philosophical meat? Why is this a philosophical topic, rather than just an exercise in philology in the classical sense? There are three distinct sets of philosophical problems related to the concept of "recognition." First, the epistemological sense ties recognition to knowledge and to memory. To recognize as...is to 


\section{CHARLES REAGAN}

understand what something is, while to recognize someone or something is to recall it. I cannot review all of the questions about memory that Ricoeur discussed at length in his book, Memory, History, Forgetting, but to recall and to recognize are both fraught with philosophical questions, such as distinguishing true memory from false memory. To recognize is the counterpart of to mis-recognize, or to fail to recognize.

The second set of meanings form a cluster that Ricoeur calls "moral" in that they involve self-recognition and other-recognition, whether one starts from the pole of the self or the pole of the other as Emmanuel Levinas does. The meaning related to expressing gratitude or appreciation falls into this category.

The third set of meanings are what I call the "political" since they involve recognition on the social and political level, especially the recognition of governments and groups. In the latter case, identity politics is centered on the question of recognition and respect for the other. What is common to all of the uses of recognition is that they all involve an act of judgment: it is this and not that; I remember him even though his appearance has changed; I understand my obligations to him; and it is a legitimate government. In each case, mis-recognition is always a possibility.

At the end of each of his major works, Ricoeur had the habit of summarizing the questions answered and the problems or aporias requiring more work. He would announce the topic of his next book and the reader could follow the itinerary of his philosophical research, not because it was all planned out in advance, but because one set of questions led to another. This book does not end this way. In fact, it ends with a quotation from Montaigne mourning his friend La Boétie:

In the friendship I speak of, our souls mingle and blend with each other so completely that they efface the seam that joined them and cannot find it again. If you press me to tell you why I loved him, I feel that it cannot be expressed, except by answering: Because it was he, because it was $I^{17}$

Since this was Ricoeur's last book, I feel it is appropriate to describe his last days. As I mentioned in the beginning of this paper, when I saw him in June of 2004, I thought it would be the last time. However, in November that year, he learned that he had won the Kluge Prize from the U.S. Library of Congress, a 


\section{RICOEUR'S LAST WORK AND DAYS}

prize equivalent to the Nobel prizes, with a $\$ 1$ million honorarium which he shared with Jaroslav Pelikan, a Yale theologian and historian of religion. Paul could not travel to the awvard ceremony, so he made a videotape of his acceptance speech, done in his living room at Chatenay-Malabry. David Pellauer, Ricoeur's long-time translator, was asked by Paul to accept the award for him, and Catherine Goldenstein, his best friend in his waning days, went as his personal representative. I attended the ceremony and when I saw the strength and effort he put into the videotape, I knew that I should go back to Paris for one last visit. This I did at the end of February 2005, just in time for his $92^{\text {nd }}$ birthday.

During the week I was there, I went to Chatenay each afternoon around 4:00pm and we would have tea and conversation. He was physically weak but mentally alert, and our conversations ranged, as they always did, from the book be was reading to current events. I would leave at 7:00 pm when a young Czech student living in the apartment downstairs would come up to have dinner with him.

This time when I left Paris, I knew that I would never see him againafter 43 years as his student, colleague, friend, and confidant. And, I was right. Catherine Goldenstein called me on Friday, May 20, 2005, to tell me that Paul had died in his sleep. I left the next day for Paris.

After arriving in Paris, I went directly to Paul's house to speak with his children. When I arrived at Les Murs Blancs (the property where Paul owned an apartment), I was greeted by Jean-Paul, Marc, Noëlle, and Etienne. I sat in the living room and had a conversation with Paul's children. I asked them the difference between the French words, "funeraille" and "obseques". Out came the Robert and the discussion began. The result was that both words refer to the same funeral rites but "funeraille" generally refers to a state funeral or one with extraordinary pomp, for example, a public funeral of a statesman. "Les obseques" refers to all of the events surrounding a funeral. We all had a good laugh that we had been trained by Paul to consult the dictionary to settle questions of meaning.

I had met Jean-Paul, Paul's oldest son, only once, in 1977, at dinner at Les Murs Blancs. At the time, their rift, caused by Jean-Paul being a Lacanian psychiatrist and the Lacanians being vitriolic opponents of Paul, had been healed and I challenged Jean-Paul on some of the main issues of Lacanism. He answered me with patience and charm. It was hard for me to believe that it had been so long. Marc, on the other hand, I had seen on many occasions, when I was staying at the house in Chatenay and he was working in Paris. Noëlle and I had been at Les Murs Blancs and at the Ricoeur's summer home at the same time on a couple of occasions, so I had seen her more often and more recently than Jean-Paul. Etienne, the youngest son and I had seen one another from time to time over the years, at Préfailles and at Chatenay. When I lived in Paris in the mid-1970s, I knew Etienne and his late brother, Olivier, quite well since they lived in the apartment 


\section{CHARLES REAGAN}

below the Ricoeur's and we had them to dinner many times.

Marc went through the order of events for the funeral the next day, and Etienne drove me to Catherine Goldenstein's house where she had prepared dinner for some of the friends of Paul's. Father Franz V ansina - to whom Paul dedicated The Course of Recognition—was one of Paul's oldest friends. Father Vansina had written the very first dissertation on Ricoeur. Also attending were Jerome Poirée, a professor at the University of Rennes, Hans-Christophe Askani, a theologian at the University of Geneva, Olivier Abel, professor of theology and philosophy at the Institute of Protestant Theology of Paris, Catherine's husband, Jean-Pierre, and myself.

Catherine Goldenstein was a friend of the Ricoeur's from the Protestant temple of Chatenay-Malabry. Beginning in the early 1990s, she would come in the afternoon to take tea with the Ricoeur's. She was a devoted companion to Simone and aided Paul immensely during the period of Simone's decline and death. She was an extraordinary friend who encouraged Paul during his bereavement. She helped him with his correspondence, made appointments for his friends' visits, and managed the household. In the last few years of his life, Catherine supervised his medical appointments and treatments and visited him daily. I know from Paul himself that, without Catherine Goldenstein and her husband Jean-Pierre, he would have died many years sooner. All of us who were friends of Paul's and loved and admired him owe her a debt of gratitude.

After a light supper, all of us left, worn out by our travels and the emotion of Paul's death. According to the arrangements, I was picked up just outside the RER station Bourg' la Reine and went with Olivier Abel and others in Hans-Christophe's car to the cemetery for the private burial service. Only the family and some close friends were invited. In the Huguenot tradition, the burial takes place before the memorial service. French Protestants believe that Catholics make a fetish of the body by having itpresent during the funeral service. In an open area just inside the cemetery, the casket was unloaded from the hearse and put on stands and surrounded by flowers. Father V ansina said some prayers. He was followed by Philippe Kabongo, the pastor of the Reformed Church of Chatenay-Malabry, who said some more prayers. Then, four men from the funeral home lifted the casket on their shoulders and walked to the grave site, with the family following next and then the few invited friends. At the gravesite, both Pastor Kabongo and Father Vansina said more prayers and the casket was lowered into the grave with ropes. Then, we all filed out and went in cars to the Reformed Church for the memorial service.

The church_or "temple" as it is called by the parishioners - was most unusual: It was underground, like in a basement of a church that was never finished. Plain concrete block walls painted white. No adornment of any kind. In the front 


\section{RICOEUR'S LAST WORK AND DAYS}

was a piano and a table and a lectern. The large crowd found seats on folding chairs. My impression was that the whole effort was to be counter the Catholic tradition of ornate churches, with paintings and statues, with pews and an elevated pulpit. The service consisted in alternating music, prayers, and eulogies. They were given by Geneviève Fraisse, the daughter of the Ricoeur's neighbors and friends, Paul and Simone Fraisse, who preceded Paul in death. She represented all of the neighbors at Les Murs Blancs. The next speaker was Olivier Abel, a long-time friend of Paul's and the son of the previous pastor of the Reformed Church of Chatenay-Malabry. He has written extensively on Paul's works and directed an hour-long documentary on Paul shown on French television. The final speaker was Antoine Garapon, the jurist who got Paul to give lectures on justice in the Advanced School for Judges in Paris. The papers he gave there are collected in the two volumes of The Just. ${ }^{18}$

When the service was finished, people mingled in the foyer of the temple and then went to Les Murs Blancs by car or on foot. There, a table was spread with food and there was more conversation. I returned to Paris to reflect on my loss: I met Paul Ricoeur 43 years before when he was a professor at the Sorbonne and I was one of his students. We really got acquainted when he came to Kansas State University to give a lecture in 1973, and he invited my wife and me to stay in his house the next year when we were on sabbatical leave in Paris. There we got to know all of his children and became special friends of Olivier. We returned to the house in the spring of 1975 and then spent a month in the Ricoeur summer home at Préfailles. A year later, we returned to France and spent a month at Les Murs Blancs before going to Toulouse where I was professor of philosophy for a year. Then, every summer, I went to Paris to see Paul, to buy books and to get his latest articles for my research. For 25 years, I visited Paul in Paris and many times I went to Chicago for a visit when he and Simone were there. During my many visits to see Paul, we would take long walks in the afternoon, to the Parc de Sceaux or the Parc de Chateaubriand, or, in Chicago the preferred walk was along Lake Michigan. I became his confidante and he discussed his personal situations with me as well as his philosophical work.

I will return to Paris, but for the first time in over forty years, it will not be to visit Paul Ricoeur.

Kansas State University

\section{Notes}

${ }^{1}$ Paul Ricoeur, The Course of Recognition trans. David Pellauer (Cambridge, MA: Harvard University Press, 2005), 3.

2 This quotation is on page 167 of the "Preface" to the Littre dictionary and quoted on page 5 of The Course of Recognition. 


\section{CHARLES REAGAN}

${ }^{3}$ Ricoeur, The Course of Recognition, 6. In the list that follows, Ricoeur is citing Littré.

${ }^{4}$ Ricoeur, The Course of Recognition, 19.

${ }^{5}$ Ricoeur, The Course of Recognition, 20.

${ }^{6}$ Ricoeur, The Course of Recognition, 66.

${ }^{7}$ Paul Ricoeur, Oneself as Another trans. Kathleen Blamey (Chicago: University of Chicago Press, 1992).

${ }^{8}$ Ricoeur, The Course of Recognition, 91.

${ }^{9}$ Ricoeur, The Course of Recognition, 94.

${ }^{10}$ Ricoeur, The Course of Recognition, 109.

${ }^{11}$ Ricoeur, The Course of Recognition, 110.

${ }^{12}$ Ricoeur, The Course of Recognition, 193.

${ }^{13}$ Ricoeur, The Course of Recognition, 212.

${ }^{14}$ Ricoeur, The Course of Recognition, 218.

${ }^{15}$ Ricoeur, The Course of Recognition, 246.

${ }^{16}$ Paul Ricoeur, Fallible Man, trans. Charles Kelbley (Chicago: Henry Regnery, 1965).

${ }^{17}$ The Complete Essays of Montaigne, trans. Donald M. Frame (Stanford, Calif.: Stanford University Press, 1957), 139. Cited in Ricoeur, The Course of Recognition, 263.

${ }^{18}$ Paul Ricoeur, The Just, trans. David Pellauer (Chicago: University of Chicago Press, 2000). Le Juste II, also translated by David Pellauer, will be published by the University of Chicago Press. 